\title{
Pulmonary involvement in systemic lupus erythematosus
}

\author{
D. M. GRENNAN, $* \dagger$ A. D. HOWIE $\ddagger$ F. MORAN $\ddagger$ AND W. W. BUCHANAN $\dagger$
}

SUMMARY Several series have suggested that pulmonary function abnormalities are common in systemic lupus erythematosus. However, only isolated studies have attempted to relate these abnormalities to immunological aspects of the disease. In the present study respiratory symptoms pulmonary function tests, and immunological data were reviewed in 22 patients with systemic lupus erythematosus. Seventeen subjects had either clinical evidence or abnormalities of lung functiou suggestive of pulmonary involvement. A restrictive ventilatory defect or reduction in pulmonaris diffusing capacity for carbon monoxide was demonstrated in 14 of the patients only 4 of whorg were dyspnoeic. There was no correlation between pulmonary involvement, co-existent renal lupus and immunological abnormality.

The lungs and pleura are commonly involved in systemic lupus erythematosus (SLE) (Winslow et al., 1958; Huang et al., 1965; Laitinen et al., 1973). Previous studies have suggested that pulmonary function abnormalities may be common in SLE in the absence of radiological abnormalities (Huang et al., 1965; Gold and Jennings, 1966). There have, however, only been isolated studies on the clinical features, pulmonary function changes and immunological aspects in patients with SLE (Holgate et al., 1976). In the present study we have assessed respiratory symptoms, pulmonary function, DNA antibody, and serum complement levels in 22 patients with SLE and examined the relationship of pulmonary involvement to immunological activity.

\section{Patients and methods}

\section{PATIENTS}

Twenty-two subjects, 17 women and 5 men, were investigated. All satisfied the preliminary criteria of the American Rheumatism Association for a diagnosis of SLE (Cohen et al., 1971). The mean age was 33 (range 14 to 69 years). Eleven patients had biopsy evidence of renal involvement. The extra renal clinical SLE disease activity excluding pulmonary

Accepted for publication February 14, 1978 Correspondence to A. D. Howie.

* Present address: Rheumatology Unit, Department of Medicine, University of Otago, New Zealand.

$\dagger$ Centre for Rheumatic Diseases, Baird Street, Glasgow G4. ¥ Centre for Respiratory Investigation, Royal Infirmary, Glasgow G4. manifestations, was graded from 0 to $+++\frac{\mathbb{2}}{3}$ Zero represented no evidence of disease activity, $\$$ evidence of disease activity without major organt involvement or fever, ++ evidence of major orgap involvement, and +++ fever greater than $38^{\circ} \mathrm{C}$ and major organ involvement. Seventeen patients vere receiving corticosteroids at the time of assessment in a daily dose of 10 to $15 \mathrm{mg}$.

\section{PULMONARY FUNCTION TESTS}

Static and dynamic lung volumes were measure using a standard vitalograph spirometer. Pulmonar diffusing capacity (transfer factor) measurement wa carried out according to the method of Ogilvie et a? (1957). The measured transfer factor values were corrected for changes in haemoglobin concentration and alveolar volume. The correction for alteration in haemoglobin concentration was made using the correction formula of Cotes et al. (1972). In nor: malisation of the transfer factor for change in alveolas volume it has been assumed that a change in lung volume of 1 litre gives a change in transfer facto of $0.867 \mathrm{mmol} / \mathrm{kPa}$ (Cotes and Hall, 1970). The vital capacity and transfer factor were considered to bo reduced if less than $80 \%$ of mean predicted.

\section{ANTI-DNA ANTIBODIES}

Anti-native DNA antibodies were measured by the Farr assay and with $\mathrm{C}^{\mathbf{1 4}}$-labelled $E$. coli native DN (Radiochemical Centre, Amersham) as antige (Hughes, 1971). The results were expressed as DNA binding capacity and the normal range $0-30 \%$. 
COMPLEMENT C3 AND C4

Serum C3 and C4 levels were measured by a radial immunodiffusion method, the normal range for $\mathrm{C} 3$ being 61-232 mg/dl and for C4 31-55 mg/dl.

\section{ANTINUCLEAR FACTOR}

This was measured using an indirect immunofluorescent technique and rat liver as substance (Beck, 1961).

\section{RHE UMATOID FACTOR}

This was measured using the R3 titration test of Denver laboratories.

\section{Results}

Table 1 summarises the respiratory symptoms and the chest radiographs in the 22 patients. Eleven patients gave a history of previous episodes of pleuritic pain. Chest radiographs showed obliteration of a costophrenic angle in 2 patients, a segmental atelectatic lesion in 1 patient, and diffuse reticular shadowing consistent with interstitial fibrosis in 1 patient.

One patient (Case 19) developed a left sided pneumothorax with $75 \%$ collapse of the left lung 6 months after the respiratory function tests shown in Table 2 were carried out. This complication occurred when he was recovering from a major disease exacerbation with pleuritic pain, pericarditis, myocarditis and fever, and when he was receiving $60 \mathrm{mg}$ prednisolone and $10 \mathrm{mg}$ of chlorambucil daily.
The respiratory function tests showed abnormalities in 16 patients (Table 2). In two of these (Cases 4 and 7), there was evidence of irreversible airways obstruction with a normal transfer factor although case 7 was a non-smoker. In the 14 other patients with abnormalities of respiratory function, 5 had reduced transfer factor alone and the remaining 9 had restrictive ventilatory defects in association with reduced transfer factor. In the latter group of 9 patients 4 were dyspnoeic but only 1 patient (case 14), had radiological evidence of interstitial fibrosis.

The immunological data are summarised in Table 3 , along with the degree of system involvement. Anti-nuclear antibody was present in all sera in titres varying between $1 / 10$ and $1 / 1000$. Rheumatoid factor in a titre of $1 / 16$ or greater was detected in 6 sera. Serum complement $\mathrm{C} 4$ levels in 21 sera tested were within the normal range in 7 and low in 14 . DNA binding capacity was increased in 16 patients, the levels being highest in those with evidence of renal involvement. There were no significant differences between patients with and without reduced transfer factor with regard to presence or absence of renal disease, mean DNA binding capacity, mean C3 level, mean C4 level, or number of patients with a positive rheumatoid factor.

\section{Discussion}

Pleuritic pain was a common feature of SLE in this as in previous series. One of our patients developed a pneumothorax after a disease exacerbation with

Table 1 Clinical and radiological features of 22 patients with SLE

\begin{tabular}{|c|c|c|c|c|c|}
\hline \multirow[t]{2}{*}{ Case } & \multirow[t]{2}{*}{ Sex } & \multicolumn{2}{|c|}{ Respiratory symptoms } & \multirow{2}{*}{$\begin{array}{l}\text { Cigarettes } \\
\text { (per day) }\end{array}$} & \multirow[t]{2}{*}{ Chest radiograph } \\
\hline & & Pleurisy & Other & & \\
\hline 1 & $\mathbf{F}$ & - & - & 20 & Normal \\
\hline 2 & $\mathbf{F}$ & - & Dyspnoea & 0 & Normal \\
\hline 3 & $\mathbf{F}$ & + & - & 10 & Normal \\
\hline 4 & $\mathbf{F}$ & + & - & 10 & Normal \\
\hline 5 & $\mathbf{F}$ & - & - & 30 & Normal \\
\hline 6 & $\mathbf{M}$ & 一 & - & 0 & Normal \\
\hline 7 & $\mathbf{M}$ & - & Wheeze & 0 & $\begin{array}{l}\text { Obliteration } \\
\text { costo-phrenic angle }\end{array}$ \\
\hline 8 & $\mathbf{F}$ & + & 一 & 0 & Normal \\
\hline 9 & $\mathbf{F}$ & 一 & - & 0 & $\begin{array}{l}\text { Segmental } \\
\text { atelectasis }\end{array}$ \\
\hline 10 & $\mathbf{F}$ & + & - & 15 & Normal \\
\hline 11 & $\mathbf{F}$ & + & Dyspnoea & 10 & Normal \\
\hline 12 & $\mathbf{M}$ & + & - & 15 & Normal \\
\hline 13 & $\mathbf{F}$ & 一 & - & $\mathbf{0}$ & Normal \\
\hline 14 & $\mathbf{M}$ & 一 & Dyspnoea & 20 & $\begin{array}{l}\text { Increased reticular } \\
\text { markings }\end{array}$ \\
\hline 15 & $\mathbf{F}$ & - & - & $\mathbf{0}$ & Normal \\
\hline 16 & $\mathbf{F}$ & + & - & 10 & Normal \\
\hline 17 & $\mathbf{F}$ & - & - & $\mathbf{0}$ & Normal \\
\hline 18 & $\mathbf{F}$ & - & 一 & 10 & Normal \\
\hline 19 & $\mathbf{M}$ & + & 一 & $\mathbf{0}$ & Obliteration costo-phrenic angle \\
\hline 20 & $\mathbf{F}$ & + & - & $\mathbf{0}$ & Normal \\
\hline 21 & $\mathbf{F}$ & + & - & $\mathbf{0}$ & Normal \\
\hline 22 & $\mathbf{F}$ & + & Dyspnoea & $\mathbf{0}$ & Normal \\
\hline
\end{tabular}


pleuro-pericardial involvement and this complication has not previously been described with SLE.

This study has confirmed the frequency of pulmonary function abnormalities in the absence of radiological abnormalities in patients with SLE. Seventeen of our 22 patients had either clinical evidence or abnormalities of lung function suggestive of pulmonary involvement. The importance of correcting the transfer factor for changes in hae- moglobin was emphasised in 2 patients (cases 8 an 21) who were anaemic during a disease exacerbation and whose uncorrected transfer factors expressed as percentage of mean predicted were $67 \%$ and $60 \%$ respectively, but corrected to $96 \%$ and $75 \%$. Two patients had irreversible airway obstruction in the absence of impairment of transfer factor. The mos济 common pulmonary function abnormality in ou patients was a restrictive ventilatory defect of

Table 2 Spirometric and gas transfer values in 22 patients with SLE

\begin{tabular}{|c|c|c|c|c|c|c|c|c|}
\hline \multirow{3}{*}{ Case } & \multicolumn{4}{|c|}{ Vital capacity $(l)$} & \multicolumn{4}{|c|}{ Diffusing capacity (transfer factor; $\mathrm{mmol} / \mathrm{min} / \mathrm{kPa}$ ) } \\
\hline & \multirow[t]{2}{*}{ Observed } & \multirow[t]{2}{*}{ Predicted } & \multirow[t]{2}{*}{ Mean predicted $(\%)$} & $F E V^{1} \%$ & \multirow[t]{2}{*}{ Observed } & \multirow[t]{2}{*}{ Predicted } & \multicolumn{2}{|c|}{ Mean predicted $\left(\% \frac{\text { న్ }}{2}\right.$} \\
\hline & & & & $F V C$ & & & & \\
\hline 1 & $1 \cdot 93$ & $2 \cdot 36-4 \cdot 12$ & 59 & 80 & $4 \cdot 0$ & $4 \cdot 4-7 \cdot 8$ & 65 & \\
\hline 2 & $1 \cdot 98$ & $2 \cdot 28-4 \cdot 04$ & 62 & 97 & $3 \cdot 8$ & $4 \cdot 4-7 \cdot 8$ & 61 & \\
\hline 3 & 3.04 & $2 \cdot 57-4 \cdot 33$ & 88 & 77 & $5 \cdot 7$ & $4 \cdot 3-7 \cdot 7$ & 98 & \\
\hline 4 & $4 \cdot 13$ & $2 \cdot 84-4 \cdot 60$ & 110 & 68 & $5 \cdot 4$ & $4 \cdot 7-8 \cdot 1$ & 83 & 0 \\
\hline 5 & $3 \cdot 80$ & $2 \cdot 93-4 \cdot 69$ & 99 & 88 & $5 \cdot 5$ & $5 \cdot 9-9 \cdot 3$ & 72 & \\
\hline 6 & $3 \cdot 56$ & $3 \cdot 06-5 \cdot 13$ & 87 & 100 & $5 \cdot 7$ & $3 \cdot 9-17 \cdot 1$ & 54 & - \\
\hline 7 & $2 \cdot 61$ & $2 \cdot 94-5 \cdot 14$ & 64 & 56 & $4 \cdot 9$ & $3 \cdot 5-6 \cdot 9$ & 94 & \\
\hline 8 & 2.97 & $2 \cdot 47-4 \cdot 23$ & 88 & 74 & $4 \cdot 5$ & $4 \cdot 2-7 \cdot 6$ & 75 & \\
\hline 9 & $3 \cdot 20$ & $2 \cdot 59-4 \cdot 35$ & 92 & 78 & $6 \cdot 0$ & $5 \cdot 8-9 \cdot 2$ & 79 & คู \\
\hline 10 & $2 \cdot 10$ & $2 \cdot 25-4 \cdot 01$ & 66 & 81 & $4 \cdot 9$ & $4 \cdot 5-7 \cdot 9$ & 79 & \\
\hline 11 & $2 \cdot 08$ & $3 \cdot 66-5 \cdot 42$ & 45 & 92 & $4 \cdot 5$ & $6 \cdot 8-10 \cdot 1$ & 53 & $\bar{\sigma}$ \\
\hline 12 & $3 \cdot 80$ & $4 \cdot 82-7 \cdot 02$ & 64 & 94 & $7 \cdot 1$ & $7 \cdot 4-10 \cdot 8$ & 78 & $\underline{\mathbb{D}}$ \\
\hline 13 & $4 \cdot 13$ & $2 \cdot 94-4 \cdot 70$ & 108 & 77 & $6 \cdot 9$ & $5 \cdot 9-9 \cdot 2$ & 90 & \\
\hline 14 & $2 \cdot 77$ & $4 \cdot 74-6 \cdot 94$ & 47 & 89 & $5 \cdot 2$ & $8 \cdot 9-12 \cdot 3$ & 48 & Оे $\overrightarrow{0}$ \\
\hline 15 & $2 \cdot 87$ & $2 \cdot 67-4 \cdot 43$ & 80 & 75 & $6 \cdot 3$ & $5 \cdot 4-8 \cdot 8$ & 88 & 으 \\
\hline 16 & $3 \cdot 27$ & $2 \cdot 63-4 \cdot 39$ & 93 & 72 & $4 \cdot 2$ & $5 \cdot 4-8 \cdot 8$ & 59 & $\leq \infty$ \\
\hline 17 & $3 \cdot 33$ & $1 \cdot 80-3 \cdot 56$ & 124 & 74 & $5 \cdot 9$ & $3 \cdot 8-7 \cdot 2$ & 107 & فํ \\
\hline 18 & $3 \cdot 20$ & $2 \cdot 73-4 \cdot 49$ & 88 & 90 & $8 \cdot 3$ & $5 \cdot 4-7 \cdot 2$ & 117 & 궁으 \\
\hline 19 & $5 \cdot 94$ & $4 \cdot 74 \cdot 6 \cdot 94$ & 101 & 77 & $6 \cdot 0$ & $8 \cdot 5-11 \cdot 9$ & 59 & $\leq$ \\
\hline 20 & $4 \cdot 42$ & $3 \cdot 46-5 \cdot 22$ & 101 & 79 & $5 \cdot 3$ & $7 \cdot 4-10 \cdot 8$ & 57 & \\
\hline 21 & $3 \cdot 15$ & $2 \cdot 99-4 \cdot 75$ & 81 & 76 & $7 \cdot 6$ & $6 \cdot 0-9.3$ & 99 & עם \\
\hline 22 & $1 \cdot 82$ & $2 \cdot 94-4.42$ & 49 & 94 & $5 \cdot 1$ & $6 \cdot 0-8 \cdot 6$ & 71 & \\
\hline
\end{tabular}

Table 3 Immunological data of the 22 patients included in this study

\begin{tabular}{|c|c|c|c|c|c|c|c|c|}
\hline Case & $\operatorname{Sex}$ & $\begin{array}{l}\text { Renal } \\
\text { involvement }\end{array}$ & $\begin{array}{l}\text { Extra-renal } \\
\text { activity* }\end{array}$ & $\begin{array}{l}D N A \\
\text { binding } \\
(\%)\end{array}$ & $\begin{array}{l}C 3 \\
(m g / d l)\end{array}$ & $\begin{array}{l}C 4 \\
(m g / d l)\end{array}$ & $A N F$ & $R 3$ \\
\hline \multicolumn{4}{|c|}{ Normal range } & $0-30$ & $61-232$ & \multicolumn{2}{|l|}{$31-55$} & \multirow[b]{2}{*}{256} \\
\hline $1+$ & $\mathbf{F}$ & - & + & 50 & 110 & 42 & 1000 & \\
\hline $2 \dagger$ & F & - & + & 9 & 147 & 47 & 1000 & $\begin{array}{r}230 \\
1024\end{array}$ \\
\hline 3 & $\mathrm{~F}$ & - & 0 & 84 & 92 & 29 & 1000 & Neg \\
\hline $4 \dagger$ & $\mathbf{F}$ & - & + & 34 & 100 & 22 & 1000 & $\mathrm{Neg}$ \\
\hline $5 t$ & $F$ & - & 0 & 64 & 160 & 38 & 1000 & $\mathrm{Neg}$ \\
\hline $6 t$ & $\mathbf{M}$ & - & + & 40 & 106 & 15 & 1000 & $\mathrm{Neg}$ \\
\hline $7 \dagger$ & $\mathbf{M}$ & - & + & 20 & 80 & 12 & 1000 & 512 \\
\hline $8 \dagger$ & $\mathbf{F}$ & - & + & 76 & 120 & 21 & 1000 & Neg \\
\hline $9 \dagger$ & F & - & + & 12 & 137 & 34 & 10 & \multirow{2}{*}{16} \\
\hline $10 \dagger$ & F & - & - & 0 & - & - & 1000 & \\
\hline $11 \dagger$ & F & - & + & 69 & 72 & 10 & 256 & $\begin{aligned} 128 \\
\mathrm{Neg}\end{aligned}$ \\
\hline $12 \dagger$ & $\mathbf{M}$ & + & + & 58 & 130 & 36 & 1000 & $\mathrm{Neg}$ \\
\hline 13 & F & + & 0 & 94 & 162 & 20 & 256 & $\mathrm{Neg}$ \\
\hline $14 \dagger$ & $\mathbf{M}$ & + & + & 56 & 96 & 17 & 1000 & $\mathrm{Neg}$ \\
\hline 15 & $F$ & + & + & 97 & 73 & 3 & 1000 & $\mathrm{Neg}$ \\
\hline $16 \dagger$ & $\mathrm{F}$ & + & + & 80 & 98 & 29 & 1000 & $\mathrm{Neg}$ \\
\hline 17 & F & + & - & 9 & 147 & 47 & 256 & 128 \\
\hline 18 & $\mathrm{~F}$ & + & 0 & 40 & 90 & 18 & 1000 & $\mathrm{Neg}$ \\
\hline $19 \dagger$ & $\mathbf{M}$ & + & $+t+$ & 90 & 100 & 60 & 250 & $\mathrm{Neg}$ \\
\hline $20 \dagger$ & F & + & + & 99 & 40 & 18 & 1000 & $\mathrm{Neg}$ \\
\hline $21 \dagger$ & $\mathrm{F}$ & + & + & 99 & 40 & 18 & 1000 & $\mathrm{Neg}$ \\
\hline $22 \dagger$ & $\mathbf{F}$ & + & $+t$ & 91 & 97 & 29 & 1000 & $\mathrm{Neg}$ \\
\hline
\end{tabular}


impairment of transfer factor and this is in keeping with the findings of others (Edmonds et al., 1975).

It has been suggested previously that patients with predominantly pulmonary involvement in SLE, had a low incidence of renal disease (Holgate et al., 1976). In the group of patients investigated here no significant difference was found in the incidence of pleuro-pulmonary disease between those with and without renal involvement.

One of our patients (case 5), had no other clinical evidence of disease activity at the time of investigation, but had a raised DNA binding capacity and antinuclear antibodies in her serum. We would agree with others (Edmonds et al., 1975) that pulmonary function tests appear valuable in demonstrating clinically latent abnormalities in patients without radiological evidence of lupus. Further follow up is required to determine whether lupus patients with asymptomatic abnormalities of pulmonary function are more likely to become symptomatic with future exacerbations of their disease and whether abnormalities of diffusing capacity improved on treatment of the disease process with corticosteroids or immunosuppressives. Our experience to date, based on the treatment of patients with symptomatic pulmonary disease suggests that this is not the case.

\section{D.M.G. is in receipt of an A. H. Robins Clinical Research Fellowship.}

The authors are most grateful to Miss G. Tully for typing the manuscript.

\section{References}

Beck, J. S. (1961). Variations in the morphological patterns of auto-immune nuclear fluorescence. Lancet, 1, 1203-1205.
Cohen, A. S., Reynolds, W. E., Franklin, E. C., Kulka, J. P., Ropes, M. W., Shulman, L. E., and Wallace, S. L. (1971). Preliminary criteria for the classification of systemic lupus erythematosus. Bulletin on Rheumatic Diseases, 21, 643-648.

Cotes, J. E., Dabbs, J. M., Elwood, P. C., Hall, A. M., McDonald, P., and Saunders, M. J. (1972). Iron deficiency anaemia: its effect on transfer factor for the lung (diffusing capacity) and ventilation and cardiac frequency during sub-maximal exercise. Clinical Science, 42, 325-335.

Cotes, J. E., and Hall, A. M. (1970). The transfer factor for the lung: normal values in adults. In Normal Values for Respiratory Function in Man, pp. 327-343, ed. by $P$. Arcangeli. Panminerva Medica: Torino.

Edmonds, J. P., Bruneau, C., and Hughes, G. R. V. (1975). Assessment of activity in S.L.E. a clinical and serological study. Annals of the Rheumatic Diseases, 34, 543-544.

Gold, W. M., and Jennings, D. B. (1966). Pulmonary function in patients with systemic lupus erythematosus. American Review of Respiratory Diseases, 93, 556-567.

Holgate, S. T., Glass, D. N., Haslam, P., Maini, R. N., and Turner-Warwick, M. (1976). Respiratory involvement in systemic lupus erythematosus; a clinical and immunological study. Clinical and Experimental Immunology, 24, 385-395.

Huang, C., Hennigar, G. R., and Lyons, H. A. (1965). Pulmonary dysfunction in systemic lupus erythematosus. New England Journal of Medicine, 272, 288-293.

Hughes, G. R. V. (1971). Significance of anti-DNA antibodies in systemic lupus erythematosus. Lancet, 2, 861-863.

Laitinen, O., Salorinne, Y., and Poppius, H. (1973). Respiratory function in systemic lupus erythematosus, scleroderma, and rheumatoid arthritis. Annals of the Rheumatic Diseases, 32, 531-535.

Ogilvie, C. M., Forster, R. E., Blakemore W. S., and Morton, J. W. (1957). A standardised breath holding technique for the clinical measurement of the diffusing capacity of the lung for carbon monoxide. Journal of Clinical Investigation, 36, 1-18.

Winslow, W. A., Ploss, L. N., and Loitman, B. (1958). Pleuritis in systemic lupus erythematosus; its importance as an early manifestation in diagnosis. Annals of Internal Medicine, 49, 70-80. 